\title{
Evaluation of chemical and physico-chemical indicators of water and bottom macrofauna the Starzyc Lake on the basis of the European Union Water Framework Directive
}

\author{
Piotr Daniszewski ${ }^{1}$, Ryszard Konieczny ${ }^{2}$ \\ ${ }^{1}$ Department of Invertebrate Zoology and Limnology, University of Szczecin, \\ 13 Waska Street, 71-415 Szczecin, Poland \\ ${ }^{2}$ Institute of Technological and Life Sciences Falenty, Branch Poznań, \\ 67 Biskupińska Street, 60-463 Poznań, Poland \\ E-mail address: daniszewski73@gmail.com
}

\begin{abstract}
Have studied lake close to neutral $\mathrm{pH} 7.70$ to 7.74. All lakes in accordance with the classification of the European Union Water Framework Directive have been included in the first class. Studies have shown a diverse water quality in lakes in relation to tested indicators. By analyzing the average annual values can be noted that the $\mathrm{pH}$ of the water, the $\mathrm{O}_{2 \text { diss }}$ and the concentration of $\mathrm{NH}_{4}{ }^{+}$, $\mathrm{NO}_{2}^{-}, \mathrm{NO}_{3}{ }^{-}, \mathrm{PO}_{4}{ }^{3-}$ diss showed a relatively small variation in all investigated Lakes. The level of the total suspended solids in Starzyc lake the peasant was on level II class. The concentration in the surface layer of $\mathrm{P}_{\text {tot }}$. Lake is little differentiated, is at level II and III quality class according to the classification of the European Union Water Framework Directive. In the case of nitrogen-compounds nitrates and nitrites values for these indicators were at level I and II class in all the surveyed lakes in accordance with the classification of the European Union Water Framework Directive. In 2008 attendance related macrofauna test bed showed that the most common they were mud-eating and larvae chironomids, oligochaeta $(\mathrm{F}=100 \%)$, which consisted of Tischlera classification of the species is absolutely solid. Among larvae of Chironomidae the species is absolutely integral were Chironomus f. l. plumosus $(\mathrm{F}=100 \%)$. However Chaoborus sp. belong to the accesoric species. Other designated species of fauna were accidental species of benthic $(\mathrm{F})=25 \%$. In 2009 attendance related macrofauna test bed showed that the most common they were mud-eating and larvae chironomids, oligochaeta $(\mathrm{F}=$ $100 \%$ ), which consisted of Tischlera classification of the species is absolutely solid. Among larvae of Chironomidae the species is absolutely integral were Chironomus f. l. plumosus $(\mathrm{F}=100 \%)$. However Asellus aquaticus Racov. and Chaoborus sp. belong to the accesoric species. Other designated species of fauna were accidental species of benthic $(F)=25 \%$. Fauna of the Starzyc Lake bottom during summer stagnation was poor in terms of quality, which proves its considerable biological degradation. In terms of the concentration in the test macrozoobenthos Lake dominated and Oligochaeta, Diptera larvae.
\end{abstract}

Keywords: water; lake; chemical and physico-chemical indicators; $\mathrm{NH}_{4}^{+} ; \mathrm{NO}_{2}^{-} ; \mathrm{NO}_{3}^{-} ; \mathrm{PO}_{4}^{3-}$ diss, macrozoobenthos; European Union Water Framework Directive 


\section{INTRODUCTION}

To address the increasing degradation of the surface waters in the European Union, changed the approach to the evaluation and protection of water resources [7-15,2029,32,35,37-48,51,56-58]. This approach was formulated in the European Union Water Framework Directive (2000/60/EC), which requires the protection of water and ecological and comprehensive approach to its assessment [5-18,21-24,27,29,32-47,50-62].

Ecological status of surface water and groundwater is assessed on the basis of the ecological potential of the biological and physico-chemical and hydromorphological [5-10, $12,14,18,23,24,27,29,32-47,50-58]$.

Implementation of the Water Framework Directive is to achieve good water status in all Member States of the European Union [3-6,8,10,11,13,15,18,24,26].

The work shows the evaluation of physico-chemical parameters of water and bottom macrofauna Starzyc Lake, based on the European Union Water Framework Directive.

\section{EXPERIMENTAL}

Lake Starzyc also called Chociwel is located in the West Pomeranian Voivodeship and is adjacent to the town of Chociwel from South and South East of the city [35]. Starzyc is the second largest lake in the municipality of Chociwel. Has an area of 59.2 ha, its length is approximately $3000 \mathrm{~m}$ and the width of the average $200 \mathrm{~m}$, his largest depth is $9 \mathrm{~m}$ is located on the Lake of $68 \mathrm{~m}$ n. p.m. flows through the settlements not Krąpiel River [35].

The Starzyc lake is characterized by the following indicators of morphometric [35]:

- $\quad$ Latitude $-\mathrm{N} 53^{\circ} 27.8$,

- Longitude - E $15^{\circ} 20$,

- mirror surface water -59.2 ha,

- capacity - $1575,8 \mathrm{~m}^{3}$,

- the maximum depth is $6.1 \mathrm{~m}$,

- the average depth is $2,7 \mathrm{~m}$,

- maximum length - $1960 \mathrm{~m}$,

- maximum width - $370 \mathrm{~m}$,

- the length of the coastline $-5175 \mathrm{~m}$.

Research was carried out in the years 2008-2009, in the period from July. At the place of sampling were numbered $\mathrm{pH}$. At the place of sampling were numbered $\mathrm{pH}$. Trying to test water were taken by Polish Standards. Collected water samples were fixed in accordance with the recommendations in the Polish Standards [7-12,14,16,19-22]. Other indicators for the quality of the waters have been tagged within 24 hours from the moment of download attempts. Determination of dissolved organic matter oxidation was vulnerable as COD-Mn in accordance with Polish Standards [7-12,14,16].

Dissolved oxygen has been marked in accordance with the methodology described by Winkler in the work of Daniszewski [7-12,14,16-21]. The degree of oxygenation of water specified by arrays in the work Nemerowa [44].

This work marked concentration of General Suspension, $\mathrm{BOD}_{5}, \mathrm{NH}_{4}^{+}, \mathrm{NO}_{2}^{-}, \mathrm{NO}_{3}^{-}$, $\mathrm{PO}_{4}{ }^{3-}$ diss, and $\mathrm{P}_{\text {tot. }}-$ in accordance with the methodology described in the work of Daniszewski (Tables 1, 2) [7-12,14,16]. 
The quality objectives was evaluated according to the criteria recommended to evaluate inland surface waters as set out in the European Union Water Framework Directive (2000/60/EC) [24].

The material from the bottom of the settlement along with fauna a groundswell of obtained using gripper Ekmana $\left(225 \mathrm{~cm}^{2}\right)$. After extraction of the gripper has a kind of sediments and the depth of bottom (Table 3). Macrozoobenthos collected from 6 posts spread over 4 transverse profiles Table 3). At each collected sedimented sample from the bottom (sample 2). "Flushed" material collected on the sieve mesh diameter $0.5 \mathrm{~mm}$ and maintained in $4 \%$ formalin solution. Segregate animals on individual taxa macroscopically and binocular Magnifier (PZO), and their density compared to $1 \mathrm{~m}^{2}$. Taxa of benthic fauna, derived from positions weigh to the nearest $0,01 \mathrm{~g}$, after drying on the filter paper. Biomass of fauna depicted in $\mathrm{g}$ wet weight per $1 \mathrm{~m}^{2}$.

Measurement of the length of the larvae were predominant at the basic slide graduated Chironomidae (to the nearest $0,5 \mathrm{~mm}$ ).

Frequencies (F) design calculated: $\mathrm{n} / \mathrm{n} \times 100 \%$ where: $\mathrm{n}$-number of posts on the where he performed the taxon $\mathrm{N}$-number of test posts.

Indicator of dominance (D) calculated from the formula: $D=S(a) / S(x) \cdot 100 \%$, where $\mathrm{S}$ is the sum of (a) animals belonging to the taxon "and", and $\mathrm{S}$ is the total biomass of macrozoobenthos in all attempts.

The interpretation of the indicator values obtained dominance and turnout has been made in accordance with the criteria given by Kasprzak and Careless (1981).

There is also an indicator of biodiversity PIE, using the formula:

$$
P I E=\frac{N}{N+1}\left(1-\sum \mathrm{p}_{i}^{2}\right) \quad p_{i}=\frac{n_{i}}{N}
$$

where $\mathrm{N}$ - total number of individuals; $\mathrm{p}_{\mathrm{i}}$ - part of the species and in the total number of individuals.

\section{RESULTS AND DISCUSSION}

The results of the Starzyc Lake are presented in Table 1 - 5.

Table 1. Results of the quality of surface water of Starzyc Lake (2008 year) along with the classification values of indicators according to the criteria of the European Union Water Framework Directive (2000/60/EC)

\begin{tabular}{|c|c|c|c|}
\hline \multicolumn{3}{|c|}{ Starzyc Lake } \\
\hline \multicolumn{3}{|c|}{$\mathbf{2 0 0 8}$ year } \\
No & $\begin{array}{c}\text { Water quality } \\
\text { indices }\end{array}$ & Units & $\begin{array}{c}\text { Average } \\
\text { (Spring, Summer, Autumn) }\end{array}$ \\
\hline 1. & Total suspended solids & $\mathrm{mg} \cdot \mathrm{dm}^{-3}$ & 20,6 (II) \\
\hline 2. & $\mathrm{pH}$ & - & 7,70 (I) \\
\hline 3. & $\mathrm{COD}^{-3 \mathrm{Mn}}$ & $\mathrm{mg} \mathrm{O} \cdot \mathrm{dm}^{-3}$ & 7,67 (III) \\
\hline 4. & $\mathrm{BOD}_{5}$ & $\mathrm{mg} \mathrm{O} \cdot \mathrm{dm}^{-3}$ & 4,47 (III) \\
\hline 5. & $\mathrm{O}_{2 \text { diss. }}$ & $\mathrm{mg} \mathrm{O} \cdot \mathrm{dm}^{-3}$ & 8,1 (I) \\
\hline
\end{tabular}




\begin{tabular}{|c|c|c|c|}
\hline 6. & $\mathrm{NO}_{3}^{-}$ & $\mathrm{mg} \mathrm{N}^{-} \mathrm{dm}^{-3}$ & 0,25 (I) \\
\hline 7. & $\mathrm{NO}_{2}^{-}$ & $\mathrm{mg} \mathrm{N}^{-3} m^{-3}$ & 0,032 (II) \\
\hline 8. & $\mathrm{NH}_{4}{ }^{-}$ & $\mathrm{mg} \mathrm{N} \cdot \mathrm{dm}^{-3}$ & 1,45 (III) \\
\hline 9. & $\mathrm{PO}_{4}{ }^{-{ }^{-}}$diss. & $\mathrm{mg} \mathrm{PO}_{4} \cdot \mathrm{dm}^{-3}$ & 0,55 (III) \\
\hline 10. & $\mathrm{P}_{\text {tot. }}$ & $\mathrm{mg} \mathrm{P} \cdot \mathrm{dm}^{-3}$ & 0,43 (III) \\
\hline
\end{tabular}

Explanation: I, II, III - classification of values of examined indicators in accordance with the European Union Water Framework Directive (2000/60/EC)

Table 2. Type of bottom deposits, depth and $\mathrm{pH}$ of interstitial waters in measurement points on Starzyc Lake (July, 2008; July, 2009)

\begin{tabular}{|c|c|c|c|}
\hline $\begin{array}{c}\text { Sampling } \\
\text { site no. }\end{array}$ & Type of bottom deposits & $\begin{array}{c}\text { Depth } \\
\text { [m] }\end{array}$ & $\begin{array}{c}\text { pH } \\
\text { of intersitial } \\
\text { waters }\end{array}$ \\
\hline 1 & $\begin{array}{c}\text { Fine sand, } \\
\text { leftover cane, } \\
\text { the remains of shells }\end{array}$ & 1,5 & 7,09 \\
\hline 2 & $\begin{array}{c}\text { Fine sand, } \\
\text { autochthonous detritus, } \\
\text { the remains of shells }\end{array}$ & 2,1 & 7,45 \\
\hline 3 & $\begin{array}{c}\text { Hamlets tanatocenozowy, } \\
\text { seashell scrap (Dreissena) }\end{array}$ & 3,5 & 7,19 \\
\hline 4 & $\begin{array}{c}\text { Hamlets tanatocenozowy, } \\
\text { seashell scrap (Dreissena), detritus }\end{array}$ & 4,9 & 7,37 \\
\hline
\end{tabular}

Table 3. Results of the quality of surface water of Starzyc Lake (2009 year) along with the classification values of indicators according to the criteria of the European Union Water Framework Directive (2000/60/EC).

\begin{tabular}{|c|c|c|c|}
\hline \multicolumn{3}{|c|}{ Starzyc Lake } \\
\hline \multicolumn{3}{|c|}{ 2009 year } \\
\hline No & Water quality indices & Units & $\begin{array}{c}\text { Average } \\
\text { (Spring, Summer, Autumn) }\end{array}$ \\
\hline 1. & Total suspended solids & $\mathrm{mg} \mathrm{dm}^{-3}$ & 18,7 (II) \\
\hline 2. & $\mathrm{pH}$ & - & 7,74 (I) \\
\hline 3. & $\mathrm{COD}-\mathrm{Mn}$ & $\mathrm{mg} \mathrm{O}_{2} \cdot \mathrm{dm}^{-3}$ & 8,0 (III) \\
\hline 4. & $\mathrm{BOD}_{5}$ & $\mathrm{mg} \mathrm{O}_{2} \cdot \mathrm{dm}^{-3}$ & 4,2 (III) \\
\hline 5. & $\mathrm{O}_{2}$ diss. & $\mathrm{mg} \mathrm{O}_{2} \cdot \mathrm{dm}^{-3}$ & 8,1 (I) \\
\hline
\end{tabular}




\begin{tabular}{|c|c|c|c|}
\hline 6. & $\mathrm{NO}_{3}{ }^{-}$ & $\mathrm{mg} \mathrm{N}^{-} \mathrm{dm}^{-3}$ & 0,34 (I) \\
\hline 7. & $\mathrm{NO}_{2}^{-}$ & $\mathrm{mg} \mathrm{N} \cdot \mathrm{dm}^{-3}$ & 0,037 (II) \\
\hline 8. & $\mathrm{NH}_{4}^{+}$ & $\mathrm{mg} \mathrm{N} \cdot \mathrm{dm}^{-3}$ & 0,89 (II) \\
\hline 9 & $\mathrm{PO}_{4}{ }^{3-}{ }_{\text {diss. }}$ & $\mathrm{mg} \mathrm{PO}_{4} \mathrm{dm}^{-3}$ & 0,62 (III) \\
\hline 10. & $\mathrm{P}_{\text {tot. }}$ & ${\mathrm{mg} \mathrm{P} \cdot \mathrm{dm}^{-3}}$ & 0,37 (II) \\
\hline
\end{tabular}

Explanation: I, II, III - classification of values of examined indicators in accordance with the European Union Water Framework Directive (2000/60/EC)

Table 4. Macrozoobenthos condensing in summer of Starzyc Lake.

\begin{tabular}{|c|c|c|c|c|}
\hline \multirow{2}{*}{ Lp. } & \multirow{2}{*}{ Taxa } & \multicolumn{3}{c|}{$\begin{array}{c}\text { Density of macrozoobenthos } \\
\text { (indiv. } \mathbf{~ m}^{-2} \text { ) }\end{array}$} \\
\cline { 2 - 5 } & & & & \\
& & 2008 & 2009 & Average \\
\hline 1. & Oligochaeta & 362 & 384 & 373 \\
\hline 2. & Hirudinea & 32 & 21 & 27 \\
\hline 3. & Isopoda - Asellus aquaticus Racov. & 15 & 19 & 17 \\
\hline 4. & Ephemeroptera larvae & 18 & 20 & 19 \\
\hline 5. & Trichoptera larvae & 19 & 24 & 22 \\
\hline 6. & Diptera larvae & 193 & 158 & 176 \\
\hline 7. & Bivalvia - Dreissena polymorpha Pall. & 8 & 30 & 19 \\
\hline 8. & Megaloptera larvae - Sialis lutaria L. & 38 & 35 & 37 \\
\hline & $\Sigma$ & 685 & 694 & 690 \\
\hline & Biodiversity index PIE & 0,795 & 0,819 & 0,807 \\
\hline
\end{tabular}

Table 5. Comparison of macrozoobenthos condensing in summer in some lakes of Western and Northern Polish

\begin{tabular}{|c|c|c|c|c|c|}
\hline \multirow[b]{3}{*}{ Taxa } & \multicolumn{5}{|c|}{ Density of macrozoobenthos (indiv. $\mathrm{m}^{-2}$ ) } \\
\hline & \multicolumn{5}{|c|}{ Lake } \\
\hline & $\begin{array}{c}\text { Jamno } \\
\text { (Piór- } \\
\text { Zasada } \\
1997 \text { ) }\end{array}$ & $\begin{array}{c}\text { Gardno } \\
\text { (Piór- } \\
\text {-Zasada } \\
1997 \text { ) }\end{array}$ & $\begin{array}{c}\text { Krzynia } \\
\text { (Gostomczyk } \\
2005)\end{array}$ & $\begin{array}{c}\text { Lubowidzkie } \\
\text { (Obolewski, } \\
\text { 2006) }\end{array}$ & $\begin{array}{c}\text { Starzyc } \\
\text { (by author) }\end{array}$ \\
\hline Oligochaeta & 272 & 1669 & 666 & 979 & 373 \\
\hline Hirudinea & 0 & 11 & 48 & 99 & 27 \\
\hline Crustacea & 0 & 0 & 146 & 2 & 0 \\
\hline $\begin{array}{l}\text { Ephemeroptera } \\
\text { larvae }\end{array}$ & 0 & 2 & 22 & 4 & 19 \\
\hline $\begin{array}{l}\text { Megaloptera } \\
\text { Sialis lutaria }\end{array}$ & 0 & 0 & 28 & 6 & 37 \\
\hline
\end{tabular}




\begin{tabular}{|l|c|c|c|c|c|}
\hline $\begin{array}{l}\text { Trichoptera } \\
\text { larvae }\end{array}$ & 0 & 0 & 53 & 12 & 22 \\
\hline Diptera larvae & 487 & 2427 & 674 & 276 & 176 \\
\hline Caretopogonidae & 0 & 2 & 0 & 0 & 0 \\
\hline Gastropoda & 0 & 0 & 7 & 0 & 0 \\
\hline $\begin{array}{l}\text { Bivalvia }- \\
\text { Dreissena } \\
\text { polymorpha }\end{array}$ & 0 & 0 & 123 & 4 & 19 \\
\hline \multicolumn{1}{c|}{$\Sigma$} & 759 & 4111 & 1767 & 1382 & 690 \\
\hline Numer of taxa & 2 & 5 & 9 & 8 & 7 \\
\hline $\begin{array}{l}\text { Biodiversity } \\
\text { index PIE }\end{array}$ & 0,920 & 0,973 & 1,990 & 0,940 & 0,807 \\
\hline
\end{tabular}

The $\mathrm{pH}$ of the water $\mathrm{pH}$ in Lakes influenced by physico-chemical and biotic interactions of environmental factors [1,4,21,26,28,32]. The degree of acidity affects directly the life processes occurring in ecosystems, among others. It is responsible for the correct download of nutrients by organisms. High alkalinity beneficial for assimilation, and the same use, located in water, nitrogen and phosphorus compounds are much more accessible than in an acid medium. Like high acidity, also clearly detrimental impact on organisms has excessive alkalinity of natural waters - $\mathrm{pH}$ above 9.0 [2,25-28,37]. Have studied lake close to neutral $\mathrm{pH}$ - 7.70 to 7.74. All lakes in accordance with the classification of the European Union Water Framework Directive have been included in the first class.

In aquatic ecosystems of lakes have experienced loss of ignition loss and not the value of the COD-Mn according to estimates, which were made on the basis of the indications of "dry residues" and "residue after ignition" in accordance with the methodology set out by Macioszczyk [31] and on the basis of the results of COD-Mn, which always values match III class water quality-tested water lakes have shown continuing in all seasons of the year quite a significant content of organic substances, including substances of a gear. The cause of this condition should be found also in the bottom of the Lakes, which is at opulent fabric of organic. The most important elements involved in primary production are phosphorus and nitrogen. The presence of these substances determines the productivity of the water body, and the same for their quality. Biogen significantly affecting the quality of water included phosphorus [1,4,7-12,31-37]. This is the primary factor constraining the development of phytoplankton. And thus affect the massive algal blooms. This element occurs in the waters the form of inorganic phosphorus and dissolved organic forms [1,2,24,25]. The mineral phosphorus, phosphates are best absorbed by organisms, which play a huge role in primary production. It is included in the circulation of matter, where content in the waters are not big get on minimum. So you should pay attention to phosphorus compounds in the demersal zone.

The forms which occur and concentrated in the water depth of the Lake and are dependent from all types to use in catchment area. Nitrogen occurs in the form of gas dissolved in the water, ammonium ions, nitrate and nitrite. In Lakes is the main factor limiting the growth of organisms $[1,2,19,22,23,25,27,29,35,40,41]$. The concentration in the surface layer of $\mathrm{P}_{\text {tot. }}$ Lake is little differentiated, is at level II and III quality class according to the classification of the European Union Water Framework Directive. Tested water lakes were changing the concentration of the $\mathrm{PO}_{4}{ }^{3-}$ diss - these concentrations correspond to water quality from III. The increase of the concentrations of phosphorus in the Lake may indicate a decrease in the amount of oxygen in the waters of the shallow and changes their status to release phosphorus compounds accumulated redox in sediment bottom [7, 8, 10, 12-15]. 
In the case of nitrogen-compounds nitrates and nitrites values for these indicators were at level I and II class in all the surveyed lakes in accordance with the classification of the European Union Water Framework Directive. Indicator, which indicates the high productivity of Lake is the biochemical oxygen demand $\left(\mathrm{BOD}_{5}\right)$. The level of this indicator values on the studied Lake was on level III class. In the remaining Lake oxygen concentration was similar (continued in I class). During the macrozoobenthos Starzyc Lake there are among the collected of organisms with eight clusters: Oligochaeta, Hirudinea, Crustacea, Insecta and Bivalvia. The most represented in terms of species was represented in August which featured Insecta cluster larvae with four rows: Ephemeroptera (Leptophlebia sp., Ephemera sp., Caenis macrura (Stephens)), Trichoptera (Limnephilidae, Leptoceridae, Cyrnus sp.) Diptera i Megaloptera (Sialis lutaria L.), (Tab. 4). The average concentration of total benthic fauna in the Starzyc Lake in the summer of 2008685 (indiv. $\cdot \mathrm{m}^{-2}$ ) (Table 4). The Greatest the importance of littoral Oligochaeta and Hirudinea, took in the larvae of Chironomidae, that accounted for $92 \%$ of the density of benthic fauna. The average concentration of total benthic fauna in the Starzyc Lake in the summer of 2009694 (indiv. $\mathrm{m}^{-2}$ ) (Table 4). The Greatest the importance of littoral Oligochaeta and Hirudinea, took in the larvae of Chironomidae, that accounted for $94 \%$ of the density of benthic fauna. In 2008 attendance related macrofauna test bed showed that the most common they were mud-eating and larvae chironomids, oligochaeta $(\mathrm{F}=100 \%$, which consisted of Tischlera classification of the species is absolutely solid. Among larvae of Chironomidae the species is absolutely integral were Chironomus f.l. plumosus $(\mathrm{F}=100 \%)$. However Chaoborus sp. belong to the accesoric species. Other designated species of fauna were accidental species of benthic $(\mathrm{F})=25 \%$.

In 2009 attendance related macrofauna test bed showed that the most common they were mud-eating and larvae chironomids, oligochaeta $(\mathrm{F}=100 \%)$, which consisted of Tischlera classification of the species is absolutely solid. Among larvae of Chironomidae the species is absolutely integral were Chironomus f.l. plumosus $(\mathrm{F}=100 \%)$. However Asellus aquaticus Racov. and Chaoborus sp. belong to the accesoric species. Other designated species of fauna were accidental species of benthic $(F)=25 \%$.

By comparing the average density of benthic fauna of the Lake with the Lake pomorskim you can see big changes in the density of taxa studied. Against this background explored Lake is characterized by high density macrozoobenthos, because the higher values were found only in Lakes (Gostomczyk 2005, Piór-Zasada 1997).

In comparison with other lakes in the Starzyc Lake is a large number of taxa, however, as a result of the distribution of non-harmonic doesn't translate to the indicator value of biodiversity PIE.

\section{CONCLUSION}

Have studied lake close to neutral $\mathrm{pH} 7.70$ to 7.74. All lakes in accordance with the classification of the European Union Water Framework Directive have been included in the first class. Studies have shown a diverse water quality in lakes in relation to tested indicators. By analyzing the average annual values can be noted that the $\mathrm{pH}$ of the water, the $\mathrm{O}_{2 \text { diss }}$ and the concentration of $\mathrm{NO}_{3}{ }^{-}$showed a relatively small variation in all investigated Lakes. The level of the total suspended solids in Starzyc lake the peasant was on level II class.

The concentration in the surface layer of Ptot. Lake is little differentiated, is at level II and III quality class according to the classification of the European Union Water Framework Directive. In the case of nitrogen-compounds nitrates and nitrites values for these indicators 
were at level I and II class in all the surveyed lakes in accordance with the classification of the European Union Water Framework Directive.

Indicator, which indicates the high productivity of Lake is the biochemical oxygen demand $\left(\mathrm{BOD}_{5}\right)$. The level of this indicator values on the studied Lake was on level III class. In the remaining Lake oxygen concentration was similar (continued in I class). Fauna of the Starzyc Lake bottom during summer stagnation was poor in terms of quality, which proves its considerable biological degradation. In terms of the concentration in the test macrozoobenthos Lake dominated, and Oligochaeta, Diptera larvae.

\section{References}

[1] Bajkiewicz-Grabowska E., J. Hydrol. Sci. 8(1-2) (1981) 63-73.

[2] Bécares E., Limnetica 25(1-2) (2006) 143-154.

[3] Brzozowska R., Dunalska J., Zdanowski B., Limnol. Rev. 5 (2005) 11-16.

[4] Brzozowska R., Dunalska J., Zdanowski B., Arch. Pol. Fish. 15(4) (2007) 445-455.

[5] Brzozowska R., Gawrońska H., Limnol. Rev. 6 (2006) 39-46.

[6] Chudecki Z., Duda L., Pol. Soil Sci. 4(2) (1971) 145-154.

[7] Cyraniak E., Daniszewski P., Draszawka - Bołzan B., International Letters of Chemistry, Physics and Astronomy 5 (2012) 88-95.

[8] Cyraniak E., Daniszewski P., Draszawka - Bołzan B., International Letters of Chemistry, Physics and Astronomy 5 (2012) 96-103.

[9] Cyraniak E., Daniszewski P., Draszawka - Bołzan B., International Letters of Chemistry, Physics and Astronomy 1 (2013) 70-77.

[10] Cyraniak E., Daniszewski P., Draszawka - Bołzan B., International Letters of Chemistry Physics and Astronomy 1 (2013) 78-84.

[11] Daniszewski P., International Letters of Chemistry, Physics and Astronomy 1 (2012) 6-12.

[12] Daniszewski P., International Letters of Chemistry, Physics and Astronomy 1 (2012) 13-16.

[13] Daniszewski P., International Letters of Chemistry, Physics and Astronomy 2 (2012) 42-45.

[14] Daniszewski P., International Letters of Chemistry, Physics and Astronomy 2 (2012) 46-52.

[15] Daniszewski P., International Letters of Chemistry, Physics and Astronomy 2 (2012) 35-41.

[16] Daniszewski P., The evolution of the geographical environment and nature protection in the industrialized and urbanized areas. 44 (2012) 16-21.

[17] Daniszewski P., Draszawka - Bołzan B., International Letters of Chemistry, Physics and Astronomy 4 (2012) 96-102. 
[18] Daniszewski P., Draszawka - Bołzan B., International Letters of Chemistry, Physics and Astronomy 4 (2012) 103-111.

[19] Daniszewski P., International Letters of Chemistry, Physics and Astronomy 4 (2012) 112-118.

[20] Daniszewski P., International Letters of Chemistry, Physics and Astronomy 4 (2012) 119-124.

[21] Daniszewski P., International Letters of Chemistry, Physics and Astronomy 5 (2012) 72-79.

[22] Daniszewski P., Konieczny R., International Letters of Chemistry, Physics and Astronomy 4 (2013) 91-97.

[23] Daniszewski P., Konieczny R., International Letters of Chemistry, Physics and Astronomy 4 (2013) 98-104.

[24] DIRECTIVE 2000/60/EC of the European Parliament and of the Council of 23 October 2000 establishing a framework for Community action in the field of water policy, 2000. Off. J. Eur. Commun. L 327, 22 December.

[25] Dzienia S., Puzynski S., Wrzesinska E., Acta Agrophysica 16(1), (2010) 25-33.

[26] Eaton A. D., Clesceri L. S., Greenberg A. E., (eds), Standard Methods for the Examination of Water and Wastewater, Ed. American Public Health Assoc., Washington 1995.

[27] Ejsmont-Karabin J., Hydrobiologia 313/314 (1995) 21-28.

[28] Fleituch T., Soszka H., Kudelska D., Kownacki A., Large Rivers vol. 13, Arch. Hydrobiol. Suppl. 141/3, No 3-4, (2002) 225-239.

[29] Garcia-Criado F., Tomé A., Vega F. J., Antolin C., Hydrobiologia, Kluwer Academic Publishers, Leon, 394 (1999) 209-217.

[30] Gostomczyk J., Makrozoobentosu characteristics of reservoir, Krzynia. Master's thesis, PAP Słupsk. 2005.

[31] Janczak J., Brodzinska B., Kowalik A., Sziwa R., Atlas Polish Lakes. T. 1. Bogucki, 1996.

[32] Kajak Z., Hydrobiology-limnology. Inland water ecosystems, PWN, Warsaw 1998, 355.

[33] Kajak Z., Ekol. Pol. 31 (1983) 495-530.

[34] Kalff J., Limnology. New Jersey 2001.

[35] Karabin A., Ekol. Pol. 33, 4, (1985) 567-616.

[36] Kasprzak K., Niedbała W., The methods used in soil zoology, PWN, Warszawa 1981.

[37] Kownacki A., Soszka H., Guidelines for the evaluation of the status of rivers on the basis of macroinvertebrates and for intakes of macro-invertebrate samples in lakes, Warsaw 2004, 51.

[38] Kubiak J., Acta Sci. Pol. Piscaria 2(1) (2003) 141-158.

[39] Kölling M., Meyniana 38 (1986) 1-19. 
[40] Lampert W., Sommer U., Ecology of inland waters. Scientific Publishing PWN, Warsaw 2001, 415.

[41] Lelek A. Canadian Special Publication of Fisheries and Aquatic Sciences 106 (1989) 469-487.

[42] Macioszczyk A., Hydrochemistry, Ed. Geology, Warsaw 1987, 475.

[43] Mudroch A., Azcue J. M., Mudroch P., (red) Influence of the use of a drainage basin on physical and chemical properties of bottom sediments of lakes, Lewis publishers Boca Raton, New York, London, Tokyo 1997.

[44] Nemerow N. L., Stream, Lake, Estuary, and Ocean Pollution, Van Nostrand Reinhold Company, New York, 1985.

[45] Obolewski K., Arch. Envir. Protec. 32(3) (2006) 67-82. (in print).

[46] Pejler B., Berzinš B., Hydrobiologia, 186/187 (1989) 137-144.

[47] Piór-Zasada A., Makrobentos przymorskich Lakes: Jamna, Gardna Wielka and Lebska with special consideration of Oligochaeta, Master's thesis. PAP Słupsk 1997.

[48] Richards C., Host G. E., Arthur J. W., Freshwat. Biol. 29 (1993) 285-294.

[49] Saksena D. N. Acta Hydrochim. Hydrobiol. 15(5) (1987) 481-485.

[50] Sládecek V., Arch. Hydrobiol. Beih./Ergebn. Limnol. 7 (1973) 1-218.

[51] Sládecek V., Hydrobiologia 100 (1983) 169-201.

[52] Trojanowski J., Antonowicz J., Król M., Bruski J., Annales of the Polish Chem. Soc. 1 (2001) 131-138.

[53] Trojanowski J., Bruski J., Baltic Coastal Zone 4 (2000) 53-66.

[54] Van Urk G., de Vaate B., Limnologie Aktuell 1 (1990) 131-145.

[55] Vollenweider R. A., Scientific fundamentals of the eutrophication of lakes and flowing waters, with particular reference to nitrogen and phosphorus as factors in eutrophication. DAS/CSIO/68.27, OECD, Paris, 1968, 192.

[56] Wright J. F., Moss D., Armitage P. D., Furse M. T., Freshwat. Biol. 14 (1984) 221-256.

[57] Zdanowski B., Ekol. Pol. 31 (1983) 287-308.

[58] Zdanowski B., Ekol. Pol. 31 (1983) 333-352. 